\title{
Landslide susceptibility mapping using the analytical hierarchy process and GIS
}

\author{
I. Semlali*, L. Ouadif and L. Bahi \\ 3GIE Laboratory, Mineral Engineering Department, Mohammadia Engineering School, Mohammed V University, Rabat, Morocco
}

\begin{abstract}
Landslide is a natural phenomenon that poses a threat and danger to humans due to the amount of damage it can cause and the different factors that can trigger it. The watershed of Oued Laou, Morocco, a part of the central Rifaine mountain chain, is a basin that is highly threatened by landslides as it is characterized by rugged terrain with steep slopes $(25 \%)$ and significant height differences. The study and prevention of this phenomenon in the area is not easy as it requires a large amount of data and access to areas whose topography is difficult. The present study therefore employs a combination of conventional statistical methods and modern digital technologies using the analytic hierarchy process and geographic information system to enable mapping of landslide susceptibility zones in the area.
\end{abstract}

Keywords: Analytical hierarchy process, geographic information system, landslides, susceptibility mapping, watershed.

DEVELOPMENT of geographic information system (GIS) has helped improve multi-criteria studies and broaden their field of application. A combination of GIS and the methods of statistical decision-making has made it possible for accurate results in map form, especially in the study of landslides in large and remote areas with highly rugged topography, where field work-based data collection is difficult. An example of such an area in Morocco is the watershed of Oued Laou. This article presents the methods and results of a study carried out to map landslide susceptibility zones in the Oued Laou watershed. This mapping is based on the use of the analytical hierarchy process (AHP) developed by Saaty ${ }^{1}$, combined with GIS processing tools.

\section{Study area}

The watershed of Oued Laou (Figure 1) is a basin on the Mediterranean coast (central coordinates: $35^{\circ} 09^{\prime} 43.7^{\prime \prime} \mathrm{N}$, $5^{\circ} 19^{\prime} 20.6^{\prime \prime} \mathrm{W}$ ), which is located in the provinces of Tetouan and Chefchaouen in northwest region of Morocco. It belongs to the central part of the Rif mountain chain known as the High Rif ${ }^{2}$. With a total area nearing

\footnotetext{
*For correspondence. (e-mail: il.semlali@gmail.com)
}

930 sq. km, the basin is characterized mainly by rugged topography with steep slopes and significant height differences.

The study area experiences heavy rainfall of up to $400 \mathrm{~mm} / \mathrm{month}$ during the winter period. However, it is characterized by three types of climates - a typical Mediterranean climate in the mountainous area, a semi-arid climate dominant in the coastal zone, and a humid climate in winter and dry during summer south of the watershed ${ }^{3}$.

Basin soils of Oued Laou watershed witness erosion and landslide due to natural factors ${ }^{4}$ (relief, climate, geomorphology and vegetation cover), anthropogenic factors $^{5}$ (clearing of forests, overgrazing and inadequate farming practices) and geological factors.

\section{Materials and methodology}

\section{AHP method}

The AHP is a semi-quantitative analytical method for decision support, where decisions are made using weights by relative comparison in pairs ${ }^{1}$. It is based on complex calculations using matrix algebra. This method has been used in many fields, such as site selection, proficiency analysis, regional planning and landslide susceptibility analysis ${ }^{6}$.

AHP is a multi-objective and multi-criteria decisionmaking approach that allows the user to arrive at a preference scale drawn from a set of alternatives. To this end, it is necessary to break down a complex unstructured problem into its components, organize these factors in an order of hierarchy, assign numerical values to subjective judgments on the relative importance of each factor, and synthesize these judgments to determine the priorities to be attributed to these factors ${ }^{7}$.

In the application of AHP, relative importance or weight of the criteria is determined after consulting with the experts ${ }^{8}$. At this level, the criteria should be compared in pairs separately using a qualitative or quantitative evaluation approach. In general, a nine-point numerical scale called the Saaty scale is recommended for comparison (Table 1).

In this hierarchical classification approach, it is also possible to check coherence by calculating the coherence or consistency ratio (CR). The latter constitutes a test of 


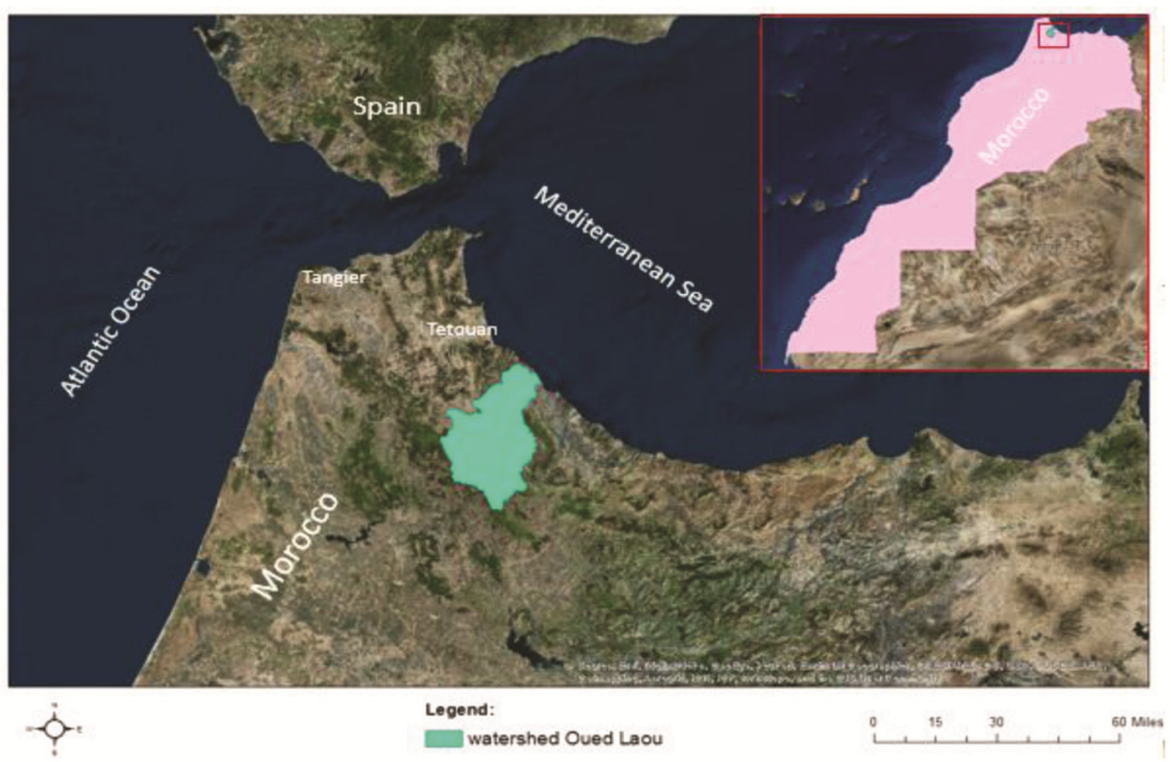

Figure 1. Location of the study area, viz. Oued Laou basin, Morocco ${ }^{3}$.

Table 1. Satty's ${ }^{1}$ scale for comparison

\begin{tabular}{lll}
\hline Scale & Degree of preference & \\
\hline 1 & Equal & Two activities contribute equally \\
3 & Moderate & Experience and judgment slightly to moderately favour one activity over another \\
5 & Strong & Experience and judgment strongly or essentially favour one activity over another \\
7 & Very strong & One activity is strongly favoured over another and its dominance is showed in practice \\
9 & Extreme & Evidence of favouring one activity over another is of the highest degree possible of an affirmation \\
$2,4,6,8$ & Intermediate values & Used to represent compromises between the preferences in weights $1,3,5,7$ and 9 \\
Reciprocals & Opposites & Used for inverse comparisons \\
\hline
\end{tabular}

Table 2. Random consistency index (RI), after Saaty ${ }^{1}$

\begin{tabular}{ccccccccc}
\hline$N$ & 3 & 4 & 5 & 6 & 7 & 8 & 9 & 10 \\
\hline RI & 0,58 & 0,90 & 1,12 & 1,24 & 1,32 & 1,41 & 1,45 & 1,49 \\
\hline
\end{tabular}

acceptance of the weights of different criteria. This step aims to detect any inconsistencies in the comparison of the importance of each pair of criteria. The coherence ratio is calculated as

$$
\mathrm{CR}=\frac{\mathrm{CI}}{\mathrm{RI}}
$$

where $\mathrm{CI}$ is the consistency index and RI is the randomized index.

The consistency index is calculated as

$$
\mathrm{CI}=\frac{\lambda_{\max }-n}{n-1},
$$

where $\lambda_{\max }$ is the maximum eigen value and $n$ is the number of criteria.
The randomized index is a value that depends on the size of the matrix, i.e. the number of criteria considered (Table 2).

According to Yurdakul et al. ${ }^{9}, \mathrm{CR}$ value must be less than 0.1 to conclude that pairwise comparison judgments are consistent. On the other hand, if CR value is greater than 0.1 , the matrix coefficients are inconsistent and cannot be used for further analysis ${ }^{10}$.

\section{Data preparation}

In the present study, we have used eight criteria as input data for the AHP method. These criteria have their direct effect on the soil and can be considered as triggering factors of landslides.

Before describing the criteria used in this study and the classification methods, it is necessary to present the general methodology used in the context of the AHP method (Figure 2).

The criteria used in this study are described below.

Slope: The main parameter of slope stability analysis is slope angle ${ }^{11}$. The angle of the slope directly affects a 


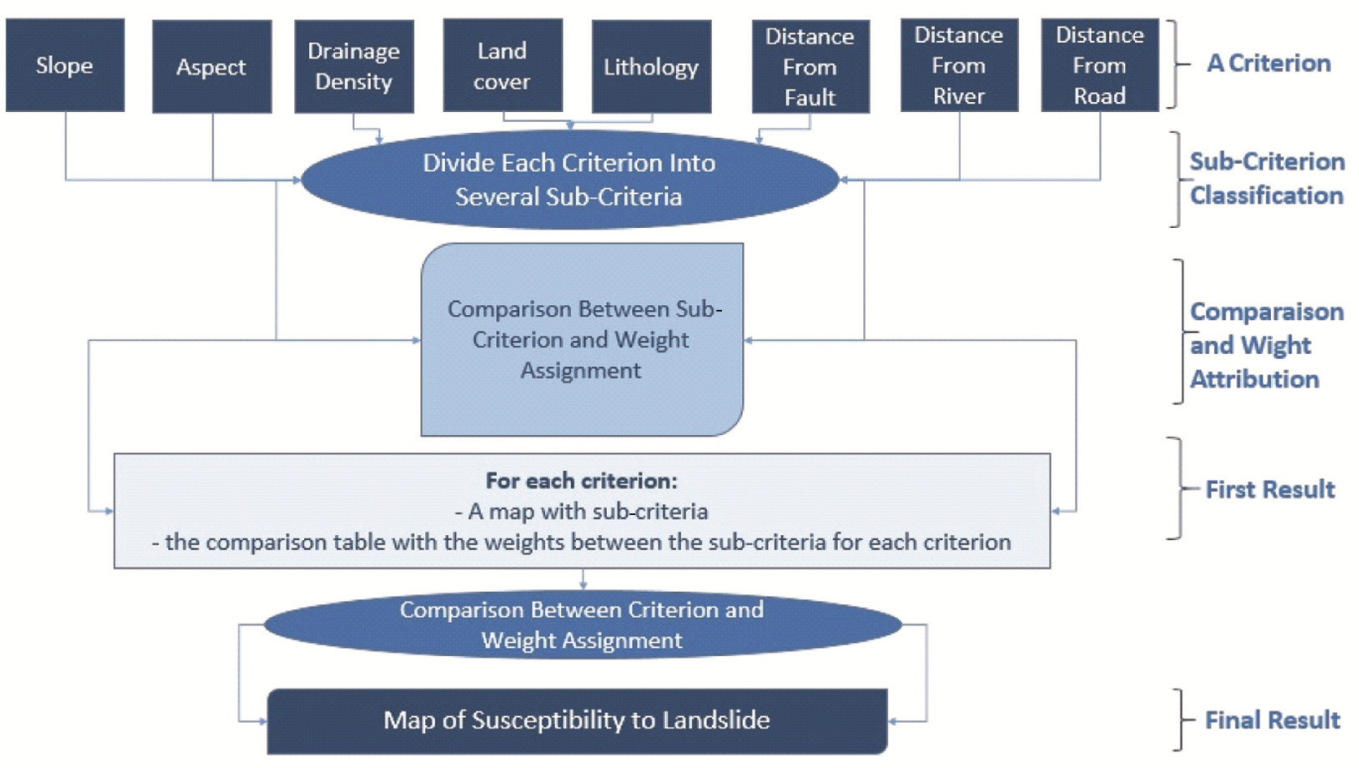

Figure 2. General methodology adopted for the analytical hierarchy process application.

Table 3. Slope sub-criterion used in the analytical hierarchy process (AHP) method

\begin{tabular}{lcccccc}
\hline Slope & $>30$ & $30-15$ & $15-5$ & $5-2$ & $<2$ & Weighting \\
\hline$>30$ & 1 & 2 & 4 & 6 & 9 & 46.88 \\
$30-15$ & 0.5 & 1 & 2 & 4 & 7 & 26.72 \\
$15-5$ & 0.25 & 0.5 & 1 & 3 & 4 & 15.19 \\
$5-2$ & 0.17 & 0.25 & 0.33 & 1 & 3 & 7.48 \\
$<2$ & 0.11 & 0.14 & 0.25 & 0.33 & 1 & 3.73 \\
\hline
\end{tabular}

$\mathrm{Cr}=0.02$.

Table 4. Aspect sub-criterion used in the AHP method

\begin{tabular}{lcccccc}
\hline Aspect & Flat & S-SW & NE-SE & W & NW-N & Weighting \\
\hline Flat & 1 & 0.5 & 0.2 & 0.2 & 0.14 & 4.53 \\
S-SW & 2 & 1 & 0.33 & 0.25 & 0.2 & 7.31 \\
NE-SE & 5 & 3 & 1 & 0.5 & 0.25 & 16.69 \\
W & 5 & 4 & 2 & 1 & 0.5 & 26.13 \\
NW-N & 7 & 5 & 4 & 2 & 1 & 45.34 \\
\hline
\end{tabular}

$\mathrm{Cr}=0.03$.

Table 5. Drainage density sub criterion used in the AHP method

\begin{tabular}{lcccccc}
\hline $\begin{array}{l}\text { Drainage } \\
\text { density }(\mathrm{Km})\end{array}$ & $2.93-2.5$ & $2.5-2$ & $2-1.5$ & $1.5-1$ & $<1$ & Weighting \\
\hline $2.93-2.5$ & 1 & 2 & 3 & 5 & 7 & 42.21 \\
$2.5-2$ & 0.5 & 1 & 5 & 4 & 3 & 31.14 \\
$2-1.5$ & 0.33 & 0.2 & 1 & 3 & 2 & 12.86 \\
$1.5-1$ & 0.2 & 0.25 & 0.33 & 1 & 2 & 7.62 \\
$<1$ & 0.14 & 0.33 & 0.5 & 0.5 & 1 & 6.17 \\
\hline
\end{tabular}

$\mathrm{Cr}=0.07$.

landslide; it is used in the preparation of landslide susceptibility maps. In this study, the slope criterion has been subdivided into five sub-criteria (Table 3 ), and was generated from topographic maps $(1: 50,000)$.
Aspect: This is also considered an important factor in the preparation of landslide risk zoning maps ${ }^{12}$. The aspect of the study area was generated from a Digital Elevation Model (DEM) derived from topographic maps on the $1: 50,000$ scale. The slope-aspect map was divided into five categories (Table 4).

Drainage density: This is defined as the proportion of the total length of water flow to the total area of the drainage basin. There is a positive correlation between drainage density and occurrence of a landslide. The drainage systems were extracted directly from the DEM (Table 5).

Land cover: This indicates the stability of slopes. Indeed, human activities can accelerate and play an important role in the occurrence of landslides ${ }^{13}$. These are water surfaces, sand or forest cannot be considered as landslide-exposed surfaces, as is the case for other types of land cover (rocks, grazing and urban centres) (Table 6).

Lithology: This has been widely recognized to greatly influence the occurrence of landslides, as lithological and structural variations often lead to a difference in the strength and permeability of rocks and soils ${ }^{14}$. The classification of lithological units in this study was made from the geological maps $(1: 50,000)$ and was based on several geological studies done on the same area (Table 7).

Distance from faults: Generally landslides are more abundant along minor and major faults. Indeed, faults are structural characteristics that describe a zone of weakness along which susceptibility to landslides is higher ${ }^{15}$ (Table 8). 
RESEARCH ARTICLES

Table 6. Land cover sub-criterion used in the AHP method

\begin{tabular}{lcccccccc}
\hline Land cover & Water & Sand and earthworks & Forest & Urban centre & Agriculture & Pasture & Rock & Weighting \\
\hline Water & 1 & 0.5 & 0.14 & 0.2 & 0.17 & 0.14 & 0.11 \\
Sand and earthworks & 2 & 1 & 0.2 & 0.25 & 0.2 & 0.17 & 0.12 & 3.26 \\
Forest & 7 & 5 & 1 & 0.5 & 0.33 & 0.25 & 0.2 & 8.87 \\
Urban centre & 5 & 4 & 2 & 1 & 0.5 & 0.33 & 0.25 & 10.6 \\
Agriculture & 6 & 5 & 3 & 2 & 1 & 0.5 & 0.5 \\
Pasture & 7 & 6 & 4 & 3 & 2 & 1 & 0.5 & 24.16 \\
Rock & 9 & 8 & 5 & 4 & 2 & 2 & 1 \\
\hline
\end{tabular}

$\mathrm{Cr}=0.046$.

Table 7. Lithology sub-criterion used in the AHP method

\begin{tabular}{|c|c|c|c|c|c|c|c|c|c|}
\hline Lithology & $\begin{array}{c}\text { Gravel and } \\
\text { sand }\end{array}$ & $\begin{array}{l}\text { Siliceous } \\
\text { arenite }\end{array}$ & $\begin{array}{l}\text { Pelite and } \\
\text { phthanite }\end{array}$ & $\begin{array}{l}\text { Shale and } \\
\text { sandstone }\end{array}$ & Limestone & Flysch & Marl & $\begin{array}{c}\text { Clayey } \\
\text { marl }\end{array}$ & Weighting \\
\hline Gravel and sand & 1 & 0.5 & 0.33 & 0.25 & 0.33 & 0.2 & 0.14 & 0.11 & 2.55 \\
\hline Siliceous arenite & 2 & 1 & 0.5 & 0.33 & 0.2 & 0.17 & 0.2 & 0.14 & 3.28 \\
\hline Pelite and phthanite & 3 & 2 & 1 & 0.5 & 0.33 & 0.33 & 0.2 & 0.17 & 5 \\
\hline Shale and sandstone & 4 & 3 & 2 & 1 & 0.5 & 0.33 & 0.25 & 0.25 & 7.43 \\
\hline Limestone & 3 & 5 & 3 & 2 & 1 & 0.5 & 0.33 & 0.25 & 10.57 \\
\hline Flysch & 5 & 6 & 3 & 3 & 2 & 1 & 0.5 & 0.33 & 15.46 \\
\hline Marl & 7 & 5 & 5 & 4 & 3 & 2 & 1 & 0.5 & 22.93 \\
\hline Clayey marl & 9 & 7 & 6 & 4 & 4 & 3 & 2 & 1 & 32.78 \\
\hline
\end{tabular}

Table 8. Sub-criterion of distance from faults used in the AHP method

\begin{tabular}{lcccccc}
\hline Distance from fault $(\mathrm{m})$ & $>2000$ & $2000-1500$ & $1500-1000$ & $1000-500$ & $500-0$ & Weighting \\
\hline$>2000$ & 1 & 0.5 & 0.33 & 0.2 & 0.14 & 5.14 \\
$2000-1500$ & 2 & 1 & 0.33 & 0.25 & 0.2 & 7.67 \\
$1500-1000$ & 3 & 3 & 1 & 1 & 0.33 & 0.5 \\
$1000-500$ & 5 & 4 & 2 & 2 & 1 & 43.63 \\
$500-0$ & 7 & 5 & 3 & & & 1 \\
\hline
\end{tabular}

$\mathrm{Cr}=0.01672$.

Table 9. Sub-criterion of distance from river used in the AHP method

\begin{tabular}{lccccccc}
\hline Distance from river $(\mathrm{m})$ & $>250$ & $250-200$ & $200-150$ & $150-100$ & $100-50$ & $<50$ & Weighting \\
\hline$>250$ & 1 & 0.5 & 0.33 & 0.2 & 0.17 & 0.13 & 3.48 \\
$250-200$ & 2 & 1 & 0.5 & 0.25 & 0.2 & 0.14 & 5.07 \\
$200-150$ & 3 & 2 & 1 & 0.33 & 0.25 & 0.17 & 7.69 \\
$150-100$ & 5 & 4 & 3 & 1 & 0.5 & 0.33 & 16.98 \\
$100-50$ & 6 & 5 & 4 & 2 & 1 & 0.5 & 25.6 \\
$<50$ & 8 & 7 & 6 & 3 & 2 & 1 & 41.18 \\
\hline
\end{tabular}

$\mathrm{Cr}=0.02230$.

Distance from river: The geomorphology of slopes touched by a stream can change and trigger landslides. The proximity of the slope to a stream can affect slope stability as the current increases the erosion of the slope and also the degree of saturation of the materials of the slope, thereby enhancing the landslide potential (Table 9).

Distance from road: Landslides can occur on slopes intersected by roads ${ }^{16}$. This is due to the fact that roads change the nature of the topography; they reduce the shear strength at the toe of the slope and cause infiltration of water in the slopes (Table 10).

\section{Results and discussion}

For each criterion used in this study, we were able to generate a map classified as a sub-criterion (Figure $3 a-d)$. 
(a)

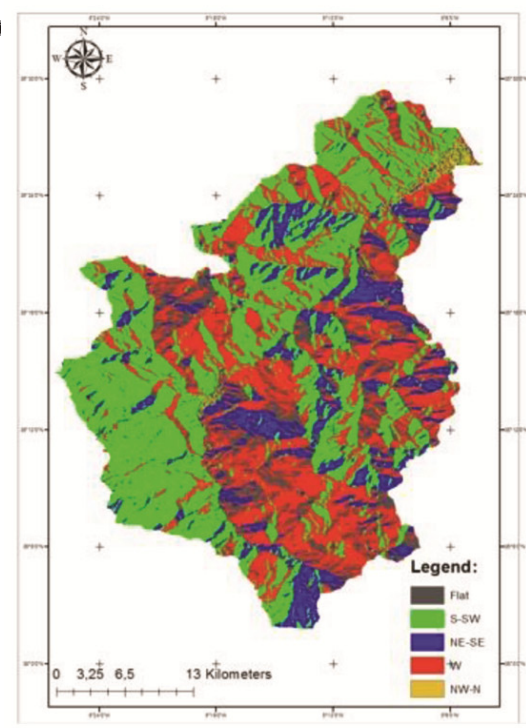

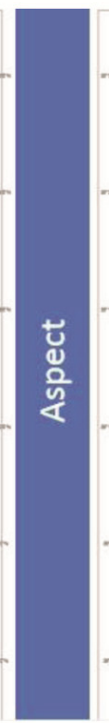

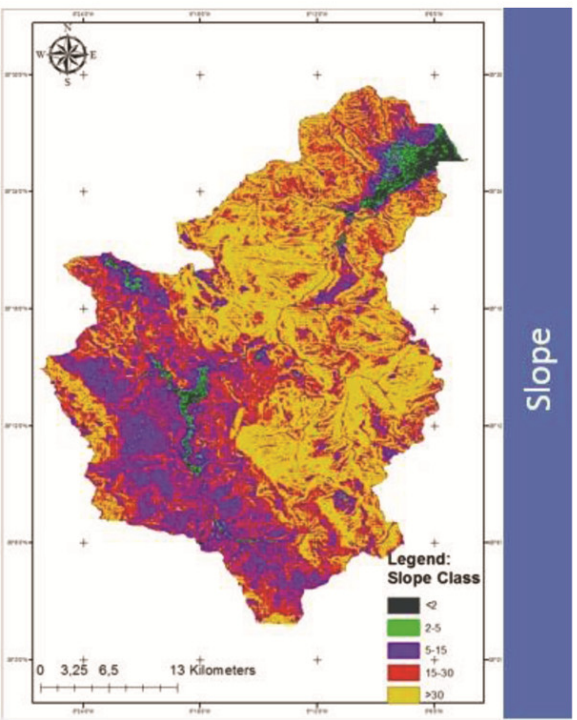

(b)
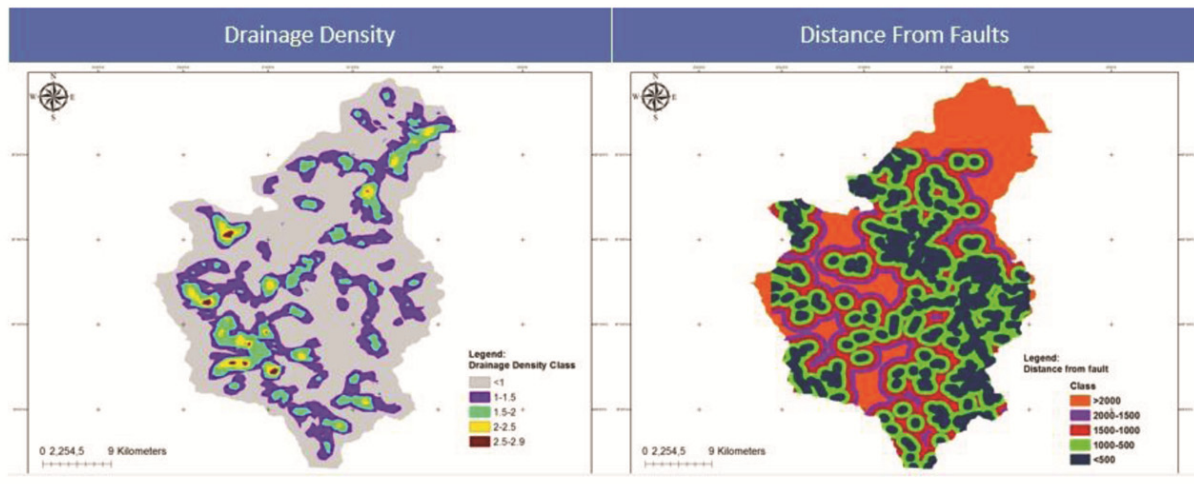

(c)

Land Cover

Lithology
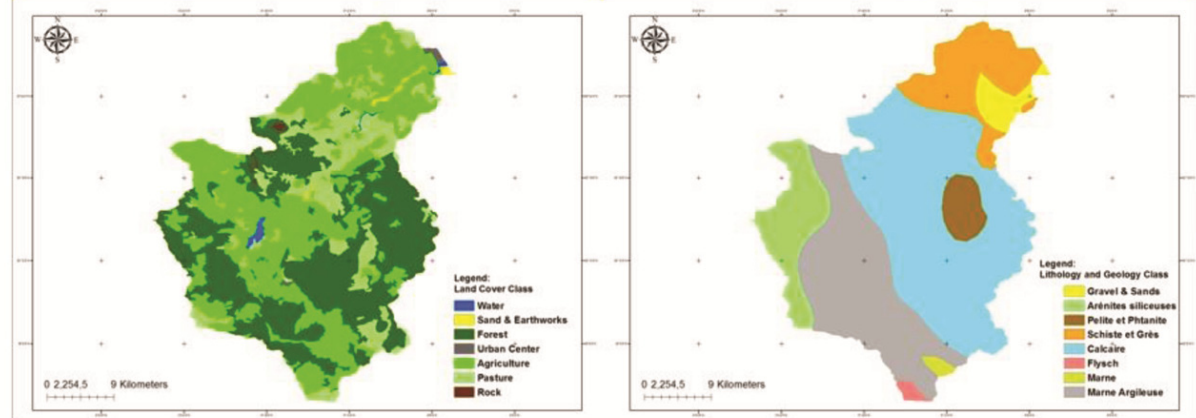

(d)

Distance From River
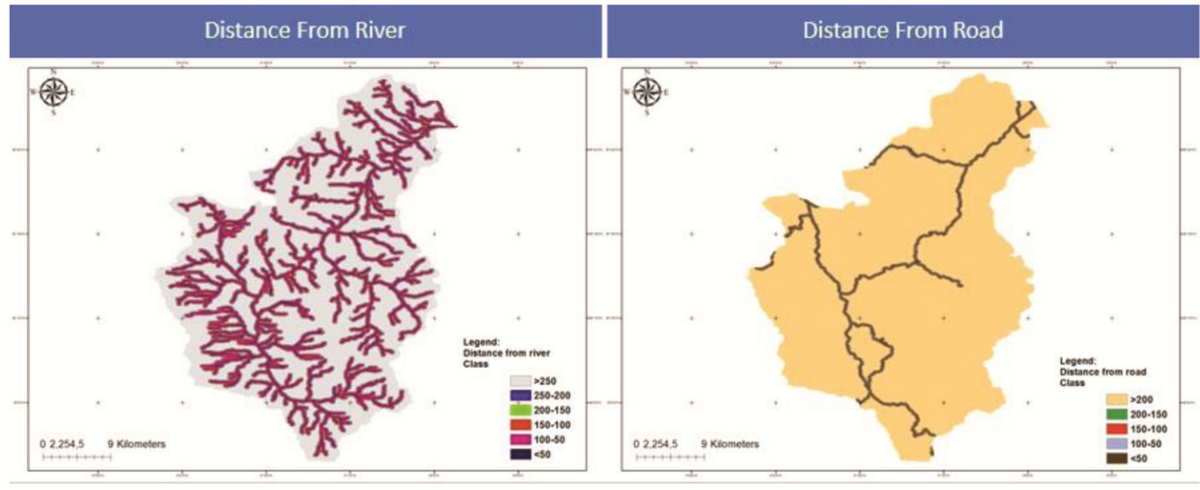

Figure $3 \boldsymbol{a}-\boldsymbol{d}$. Maps of each criterion with its sub-criteria. 
Table 10. Sub-criterion of distance from road used in the AHP method

\begin{tabular}{lcccccc}
\hline Distance from road $(\mathrm{m})$ & $>200$ & $200-150$ & $150-100$ & $100-50$ & $50-0$ & Weighting \\
\hline$>200$ & 1 & 0.33 & 0.33 & 0.25 & 0.17 & 5.44 \\
$200-150$ & 3 & 1 & 0.5 & 0.33 & 0.25 & 10.58 \\
$150-100$ & 3 & 2 & 1 & 0.5 & 0.33 & 15.73 \\
$100-50$ & 4 & 3 & 2 & 1 & 0.5 & 25.87 \\
$50-0$ & 6 & 4 & 3 & 2 & 1 & 42.38 \\
\hline
\end{tabular}

$\mathrm{Cr}=0.02273$.

Table 11. AHP matrix

\begin{tabular}{|c|c|c|c|c|c|c|c|c|c|}
\hline $\begin{array}{l}\text { Comparison of } \\
\text { the criteria }\end{array}$ & Slope & Lithology & $\begin{array}{l}\text { Land } \\
\text { cover }\end{array}$ & $\begin{array}{l}\text { Distance } \\
\text { from fault }\end{array}$ & $\begin{array}{l}\text { Distance } \\
\text { from river }\end{array}$ & $\begin{array}{l}\text { Distance } \\
\text { from road }\end{array}$ & Aspect & $\begin{array}{l}\text { Drainage } \\
\text { density }\end{array}$ & $\begin{array}{l}\text { Criteria } \\
\text { weights }\end{array}$ \\
\hline Slope & 1 & 2 & 3 & 5 & 5 & 6 & 7 & 8 & 32.1721 \\
\hline Lithology & 0.5 & 1 & 2 & 4 & 3 & 5 & 6 & 7 & 21.7699 \\
\hline Land cover & 0.333 & 0.5 & 1 & 4 & 5 & 6 & 7 & 8 & 20.1825 \\
\hline Distance from fault & 0.2 & 0.25 & 0.25 & 1 & 2 & 4 & 6 & 8 & 10.1752 \\
\hline Distance from river & 0.2 & 0.333 & 0.2 & 0.5 & 1 & 2 & 4 & 6 & 6.8744 \\
\hline Aspect & 0.143 & 0.167 & 0.143 & 0.167 & 0.25 & 0.5 & 1 & 2 & 2.6377 \\
\hline Drainage density & 0.125 & 0.143 & 0.125 & 0.125 & 0.167 & 0.2 & 0.5 & 1 & 1.8452 \\
\hline
\end{tabular}

$\mathrm{Cr}=0.0737$.

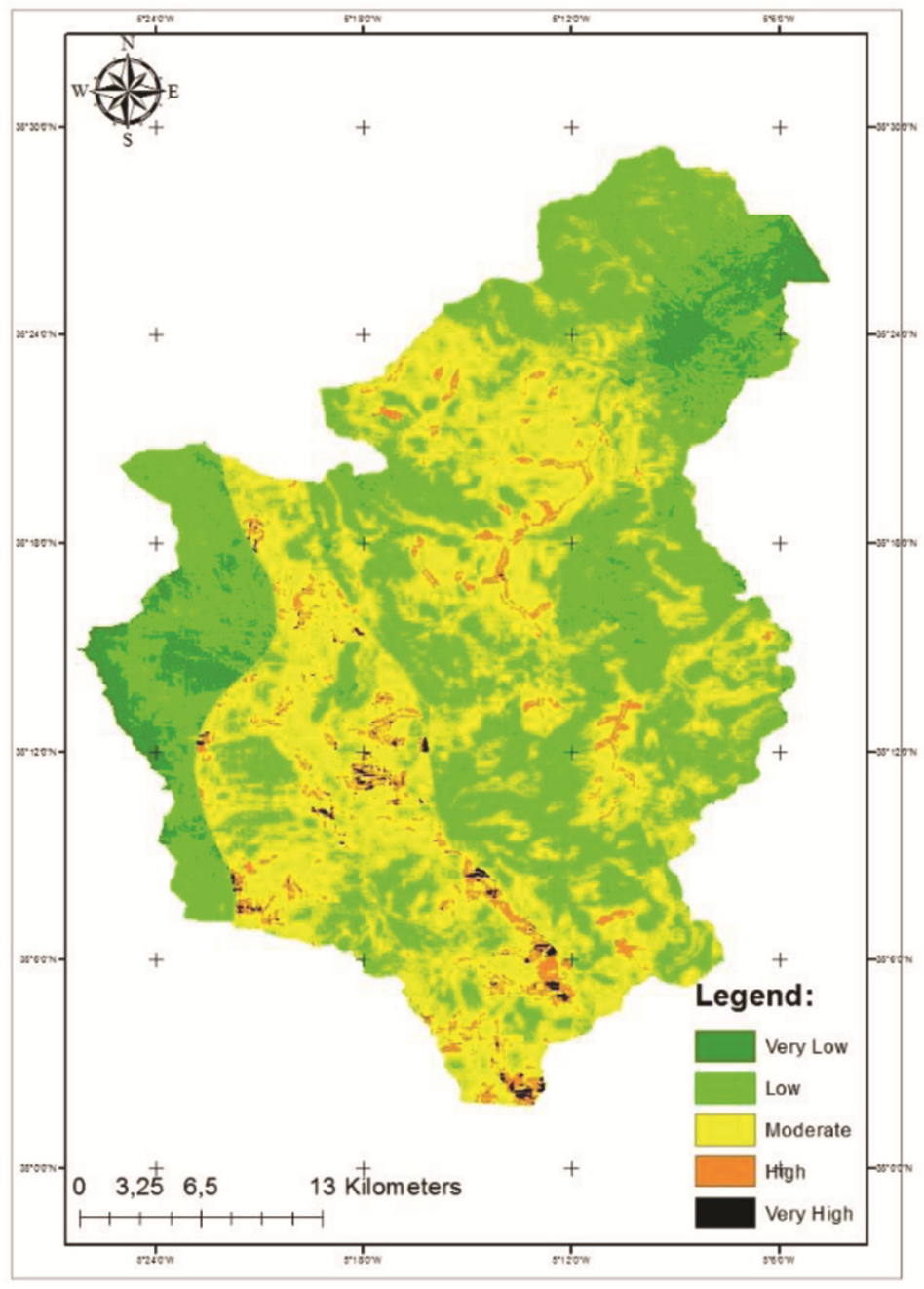

Figure 4. Landslide susceptibility map. 
Table 11 shows results of the AHP method used for the eight criteria considered in this study.

A consistency ratio of 0.0737 indicates that it is less than the threshold value of 0.1 . Using GIS tools, a map of susceptibility to landslides in the study area was generated (Figure 4).

The result obtained was compared and validated with data collected in the field throughout the watershed, and with the results of other studies carried out as a part of the hydrological modelling of the Oued Laou watershed and the study of the multi-temporal stability of the soil. These comparisons confirmed that more than $80 \%$ of the sites obtained in the susceptibility map are actually exposed to the risk of landslides. The susceptibility map has been divided into five classes depending on their degree of importance:

(i) Areas with very high susceptibility to landslides, $0.37 \%$ of the total area of the watershed.

(ii) Areas with high susceptibility to landslides, $3.56 \%$ of the total area of the watershed.

(iii) Areas with moderate susceptibility to landslides, $44.13 \%$ of the total area of the watershed.

(iv) Areas where susceptibility to landslides is low to very low, that constitute consecutively $45.88 \%$ and $6.05 \%$ of the surface area of the watershed.

\section{Conclusion}

In this study, we used the AHP method and GIS technique to generate a landslide susceptibility map of the Oued Laou watershed in Morocco. Considering the overall surface of the study area, which is $930 \mathrm{sq}$. $\mathrm{km}$, and the amount of data used in the study, we conclude that the results obtained in this study are satisfactory. However, these results can be improved, either by introducing other criteria which have a direct or indirect influence on landslides and which were not taken into account in this study, or by developing the criteria already used such as lithology and land cover, and using maps or basic data with higher resolution to improve the accuracy of the AHP method and therefore that of the landslide susceptibility map.
1. Saaty, T. L., The Analytical Hierarchy Process, McGraw Hill, New York, USA, 1980.

2. Stitou El Messari, J. and Salhi, A., Approche hydrogéologique. WADI Project of the European Union, the Activities Report, 2007.

3. Semlali, I., Ouadif, L., Baba, K., Akhssas, A. and Bahi, L., Using GIS and SWAT model for hydrological modelling of Oued Laou Watershed (Morocco). ARPN J. Eng. Appl. Sci., 2017, 12(23), 6933.

4. Harmouzi, H., Dekayir, A., Rouai, M. and Afechkar, M., Analyse géomorphologique et géologique du glissement de terrain d'Akchour (Rif, Maroc). Geo-Eco-Trop., 2018, 42(1), 19-32.

5. Mastere, M., Van Vliet-Lanoe, B. and Ait Brahim, L., Évaluation de la susceptibilité aux mouvements de terrain par approche probabiliste. In Application à la zoneméditerranéenne entre Jebha et Oued Laou, Presses universitaires de la Méditerranée, 2018, ISSN 1956-4252.

6. Rakotoarivelo, J. B., Analyse Comparative de Méthodes Multicritères d'aide à laDécision pour le Secteur financier. Research report IRIT no. IRIT/RR_2015_07_FR.

7. Saaty, T. L. and Vargas, G. L., Models, Methods, Concepts, and Applications of the Analytic Hierarchy Process, Kluwer, Boston, USA, 2001

8. Ben Jeddou, M. and Bali Kalboussi, W., Application de la méthode AHP pour le choixmulticritères des fournisseurs. Moroccan J. Res. Manage. And Market., No. 12, August-October 2015.

9. Yurdakul, M. and Tansel, Y., AHP approach in the credit evaluation of the manufacturing firms in Turkey. Int. J. Prod. Econ., 2004, 88, 269-289.

10. Wong, J. K. and Li, H., Application of the analytic hierarchy process (AHP) in multi-criteria analysis of the selection of intelligent building systems. Build. Environ., 2007, 43(1), 108-125.

11. Lee, S. and Min, K., Statistical analysis of landslide susceptibility at Yongin, Korea. Environ. Geol., 2001, 40, 1095-1113.

12. Yalcin, A., GIS-based landslide susceptibility mapping using analytical hierarchy process and bivariate statistics in Ardesen (Turkey). Catena, 2008, 72, 1-12.

13. Cheng, Z. and Wang, J., Landslide hazard mapping using logistic regression model in Mackenzie Valley, Canada. Nat. Hazards, 2007, 42, 75-89.

14. Champati Ray, P. K., Fuzzy-based method for landslide hazard assessment in active seismic zone of Himalaya. Landslides, 2007, 4, 101-111.

15. Pourghasemi, H. R., Landslide hazard assessment using fuzzy multi criteria decision - making method. Iran. J. Watershed Manage. Sci. Eng., 2009, 3(8), 51-62.

16. Nielsen, T. H., Wrigth, R. H., Vlasic, T. C. and Spangle, W. E., Relative slope stability and land-use planning in the San Francisco Bay region, California. US Geological Survey Professional Paper 944, 1979.

Received 28 June 2018; revised accepted 26 November 2018

doi: $10.18520 / \mathrm{cs} / \mathrm{v} 116 / 15 / 773-779$ 